\title{
Edward Hopper Resimlerinde Amerikan Günlük Hayatının ve Modern Yaşamın İzleri
}

\author{
Traces of Daily American Life And Modern Life in The Paintings of Edward \\ Hopper
}

Altay Aldoğan

Arş. Gör., Anadolu Üniversitesi Güzel Sanatlar Fakültesi Resim Bölümü, aldoganaltay@hotmail.com

\section{$\ddot{O} \mathbf{z}$}

Edward Hopper'ın Amerikan günlük yaşamına ait görünümlerden oluşan eserleri, sanayileşmenin gelişmesiyle birlikte yalnızlaşan bireyi öne çıkaracak şekilde kurgulanmıştır. Bu sebeple sanatçının resimlerinin anlaşılması için öncelikle 20.yy Amerika'sının içinde bulunduğu koşullar değerlendirilmiş ve modern bireyin yalnızlığı, yabancılaşması ve yalıtılmışlığı üzerinde durulmuştur. Hopper'ın resimlerindeki karamsar havayla ilişki kurularak ülkenin içinde bulunduğu savaş döneminden ve ekonomik krizden bahsedilmiştir. Sanatçının beslendiği bu kaynaklar ifade edildikten sonra Automat (1927), Room in New York (1932), New York Movie (1939), Nighthawks (1942), Western Motel (1957) isimli çalışmalar, Amerikan yaşam tarzı ve taşıdığı modern hayata ait izler üzerinden tarihsel ve sosyolojik açıdan eleştiri yöntemiyle incelenmiştir. Bu inceleme esnasında; ressamın kompozisyonlarında kullandığı elemanlar, konuya yaklaşım şekli ve resimlerinin biçimsel öğeleriyle 20. yy Amerikan toplum yapısı arasında ilişki kurulması amaçlanmaktadır. Kurulan bu ilişki; bireyin, modern yaşam tarzıyla birlikte toplum içerisinde değişen konumunu göstermesi açısından önem taşıdığı gibi aynı zamanda Hopper'ın resimlerine belge niteliği de kazandırmaktadır.

Sanatçının eserleri incelendiğinde kendisinin de ait olduğu 20. yy Amerikan toplumunu ve kültürünü gösterme kaygısı içinde olduğu açıkça görülür. Dolayısıyla 1900'lü yıllarda Amerika merkezli ortaya çıkan İkinci Sanayi Devrimi'nin sonucu olarak gelişen modern hayatı anlatan bu eserler, bireyin modernite ile ilişkisini vurgulamakta ve sanatçının dış dünyanın gerçeklerini betimleme arzusunu göstermektedir.

Anahtar kelimeler: Edward Hopper, Günlük Yaşam, Modern Hayat, Yalnızlık, Yabancılaşma

\begin{abstract}
The works of Edward Hopper that consist of images of daily American life are structured in a way to reflect the individual who is isolated with the development of industrialization. For this reason, in order to understand the paintings of the artist, firstly the conditions of the United States in the 20th century were discussed, and the loneliness, alienation and isolation of the modern individual were focused on. The era of war and economic crisis the country was involved in was elaborated upon by establishing a relationship with the pessimistic ambiance in the paintings of Hopper. After describing these sources utilized by the artist, the works named Automat (1927), Room in New York (1932), New York Movie (1939), Nighthawks (1942) and Western Motel (1957) were historically and sociologically examined with the critical method through the American lifestyle and the traces it carries regarding modern life. During this examination, it was aimed to make an association between the elements used by the painter in his compositions, his way of approaching the topic and the stylistic elements of his paintings and the
\end{abstract}


American social structure in the 20th century. This association is not only important as it shows that changing position of the individual in the society against the modern lifestyle, but also provides Hopper's paintings with the quality of documents.

When artist's works are examined, it is clear that the artist is in the concern of showing the 20th century American society and culture to which he belongs. Therefore, these works, which describe the modern life as a result of the Second Industrial Revolution that emerged in America in the 1900s, emphasize the relationship of the individual with modernity and show the artist's desire to describe the realities of the outside world.

Keywords: Edward Hopper, Daily Life, Modern Life, Loneliness, Alienation

\section{Giriş}

Ressam Edward Hopper (1882-1967) 1920'li yıllardan itibaren Amerika'ya ait şehir yaşamından sahneler ve doğa görünümlerini çalışmalarına konu olarak seçmiştir. Resimlerinde yer alan şehir hayatı neredeyse terkedilmiş sokak ve binalardan oluşur. Peyzajlarında ise tabiatın ortasında her şeyden yalıtılmış bir şekilde duran yapılar bulunmaktadır. Figürler ise ister tek, ister bir arada olsun bireyin tek başınalığını öne çıkaracak şekilde kurgulanmıştır. Sanatçı, günlük yaşamı konu alan eserleri aracılığıyla modern toplumları ve bu toplumların gelişimi karşısında insanların yaşam biçimlerindeki kaçınılmaz değişimleri de resmetmiştir. Aynı zamanda bu değişimleri, özellikle şehirlerdeki beton bloklar arasında sıkışıp kalan insanın konumu ve bu insanların birbirleriyle olan iletişimindeki kopukluklar üzerinden anlatarak çağının yalnızlaşmış ve yabancılaşmış bireylerini öne çıkarır.

Sanatçının resimlerini anlayabilmek için 20. yüzyıl Amerika'sında yaşanan bazı sosyolojik kırılma noktaları oldukça önemlidir. Bu yüzyılda sanayileşmenin gelişmesiyle birlikte şehir nüfusu artmış, bunun paralelinde şehirlerin ve insanların tek tipleştiği bir ülke görünümü ortaya çıkmıştır. Kapitalist düzenin 1930'lu yıllarda yaşadığg "Büyük Buhran" ile etkileri dünya çapında görülen bir kriz sürecine giren Amerika, aynı zamanda iki dünya savaşını birden yaşamıştır. Tüm bu travmatik olayların yaşandığı döneme tanıklık eden Hopper; bu olayların Amerikan toplumundaki yansımalarını kendisine kaynak olarak seçmiş ve resimlerinde bu durumu yansıtmıştır. Sanatçının; resimleri için seçtiği bu konu, konuyu seçme nedenleri ve dönemin kent hayatı ile birey arasındaki ilişkinin 20. yüzyıl Amerikan toplum yapısı ile bağlantı kurularak incelenmesi bu araştırmanın problemini oluşturmaktadır.

Sanatçının gerçekçi bir üslupla, Amerikan yaşamına ait görünümlerden oluşan eserleri, sadece şehrin ve yalnızlaşmış bireyin şehir hayatının değil aynı zamanda çă̆ının da açı bir tasviridir. Bu sebeple Hopper'ın eserlerinin çözümlenmesi yaşadığı dönemin birey-toplum ilişkisinin tespiti anlamında da önemlidir. Buradan hareketle sanatçının resimlerine o günden bakmak ve yaşadığı yüzyılı referans alarak sınırlamak hem konunun daha anlaşılır olmasını hem de tespitlerin yerindeliğini sağlayacaktır. Dolayısıyla Hopper'ın sanat anlayışı yaşadığı çağın koşullarıyla bağlantılı olarak anlatılacak, eserleri döneminin sosyal yaşamı ile ilişkilendirilerek konu ve biçim anlamında incelenecektir. Araştırma; sanatçının eserleri arasından seçilen Automat (1927), Room in New York (1932), New York Movie (1939), Nighthawks (1942), Western Motel (1957) isimli çalışmalar ile sınırlandırılmıştır. 


\section{Yöntem}

Araştırmada Betimsel Yöntem kullanılmıştır. Alan yazında literatür taraması yapılarak, yöntem dahilinde Edward Hooper'ın resimlerinin anlaşılması için 20.yy Amerika'sının içinde bulunduğu koşullar değerlendirilmiş ve modern bireyin yalnızlı̆̆ , yabancılaşması ve yalıtılmışlı̆̆ üzerinde durulmuştur. Sanatçının Automat (1927), Room in New York (1932), New York Movie (1939), Nighthawks (1942), Western Motel (1957) isimli çalışmaları, Amerikan yaşam tarzı ve taşıdığı modern hayata ait izler üzerinden tarihsel ve sosyolojik açıdan eleştiri yöntemiyle incelenmiştir. Bu inceleme esnasında; ressamın kompozisyonlarında kullandığı elemanlar, konuya yaklaşım şekli ve resimlerinin biçimsel öğeleriyle 20. yy Amerikan toplum yapısı arasında ilişki kurulması amaçlanmıştır.

\section{Edward Hopper}

1882 yılında New York'ta doğan ressam Edward Hopper resim eğitimi aldığı New York Sanat ve Tasarım Okulu'ndan 1906 yılında mezun olmuş ve sonrasında sanat olaylarını izlemek için Fransa başta olmak üzere birçok Avrupa şehrinde bulunmuştur. Ancak modernist akımlardan pek etkilenmemiş, çağdaşlarının aksine gerçekçi ressamlar dikkatini çekmiştir. 1910'da Amerika'ya dönen Hopper geçimini sağlamak için bir yandan illüstratörlük yaparken bir yandan da kır ve kent manzaraları yapmıştır. Bu manzaralarda sadeleştirdiği biçimsel öğeler, 1şık-gölge kontrastlıkları ve mimari yapılar eşliğinde resmedilen günlük yaşam sahneleri sıklıkla yalnızlık, sessizlik, melankoli, yabancılaşma gibi kavramlarla ilişkilendirilir. Kurulan bu ilişki ancak 20. yy Amerika'sının modern kent hayatı ve bu hayatın bireyler üzerindeki etkileri çerçevesinden bakıldı̆̆ında anlam kazanır. Bu sebeple Hopper'ın resimlerinin anlaşılması için ilk olarak dış dünya gerçekliğinin referans alınması gerekir.

Bu noktada söylenecek ilk şey 20. yy'da modern hayatı oluşturan gelişmelerin başında yer alan ve Amerika merkezli ortaya çıkan İkinci Sanayi Devrimi'dir. Sosyolog Server Tanilli (2007, s. 44-46) bu devrimi oluşturan başlıca unsurları; elektriğin kullanıma girmesi, petrolün kömürün egemenliğine darbe vurması, maden ve kimya sanayilerinde yaşanan teknik ilerlemeler sayesinde yeni üretim biçimleri ve ürünlerin ortaya çıkması olarak sıralar. Bu gelişmelerle birlikte üretimde büyük görevi makineler üstlenirken, zanaatçıllı̆ın bakım ve onarım işlerine doğru kaymasına sebep olmuştur. Gelişen teknolojiyle basit mekanik aletler, kompleks makinelere dönüşmüş, bu durum seri üretime geçilmesini sağlamış ve bu yolla büyüyen kent sanayisi kentlerdeki nüfusun artmasına yol açmıştır. 20. yy Amerika'sında yaşanan tüm bu dönüşümler bireyin üretim sürecindeki rolünü değiştirirken aynı zamanda Hopper'ın resimlerinin de kahramanı olan "modern bireyi" biçimlendirmeye başlamıştır. Bu biçimlendirmenin ayaklarından ilki makine karşısında işçinin konumu ve bu konumun yarattığ1 sonuçlardır. Tanilli' nin (2007, s. 560) “....makine, onu kullanana sürekli ve dayanılması güç bir çaba yüklüyor ve eski kas yorgunluğunun yerini genel ve ağır bir bitkinlik alıyor, bir aşınma içine giriyor insan" sözleri iş̧̧inin içinde bulunduğu yeni durumu özetler niteliktedir. Ancak makineler sadece kendisiyle beraber çalışmakta olan işçileri değil, günlük hayata varana kadar her alanı dönüştürmeye başlamıştır. "...fabrikada olduğu gibi büroda da, makine insanın yerine geçmiştir, dinleyen, okuyan, hesaplayan, yazan hep makinedir..." (Tanilli, 2007, s. 559) ifadesinde de belirtildiği gibi makinelerin üretim sürecinde aldıkları rolün etkileri fabrika sınırları dışına çıkarak tüm hayatı kuşatmış, adeta kimsenin kaçamayacağ 1 bir hal almıştır.

Hopper'in resimlerinde de bu durum net bir şekilde görülür. Sanat tarihçisi Jessica Murphy (2007) sanatçının çalışmalarında yer alan figürlerin nadiren kendi evlerinde gösterildiğini, bunun yerine, sinema salonları, otel odaları veya restoranlar gibi kamusal alanlarda vakit geçirdiklerini söyleyerek, Hopper'ın gündelik hayatın çeşitli anlarını resmettiğini belirtir. Bu durum sanatçının çalışmalarının, hayatın her anında etkileri hissedilen modernite ile ilişkisinin tespiti açısından önemlidir. 
Teknolojik gelişme ve insan arasındaki ilişkiden söz ettikten sonra, bu gelişmeye paralel olarak büyük kalabalıkların yaşadığı şehirler modern hayatın merkezi durumuna gelmiş ve bu merkezin öznesi olarak modern bireyin kalabalıklar içerisindeki konumu önemli bir hal almıştır. Bu bağlamda sosyolog George Simmel'in (2003) ve Fritz Pappenheim'ın (2002) “Modern İnsanın Yabancılaşması" isimli kitabında yer alan aşağıdaki sözleri Hopper' in resimlerinin anlaşılması için önemli bir anahtar rolü üstlenecektir.

...bedensel yakınlık ve mekân darlığı, zihinsel uzaklığı daha da görünür kılmaktadır. Metropol kalabalığıyla kıyaslandığında, insanın kendisini böylesine yalnız, böylesine kaybolmuş hissettiği başka bir yer yoktur (Simmel, 2003, s. 96).

Basitçe çoğunluktan biri olarak var olmak, sanki her şey olabileceğinin en iyisiymiş gibi insanı derinden yatıştıran bir etki yaratır. Bu yatışma cazip olmasına caziptir ama çok yüksek bir bedel ödemeden insanın bunu elde etmesi olanaksızdır. Bedel olarak kendi olmaya son vermek, kendi benliğinden uzaklaşmak zorunda kalacaktır (Pappenheim, 2002, s. 22).

Simmel ve Pappenheim'ın bu sözleri kalabalıklar içerisinde yer alan bireyin modern hayattaki ruh halini anlatmakta, sanatçının resimlerinin açıklanmasında sürekli vurgulanan yalnızlık ve yabancılaşmanın da kaynağını oluşturmaktadır.

Hopper'ın popülerliğini Amerikan ruhunun derinliklerinde bir şeye dokunmasına bağlayan yazar Edward Lucie-Smith "Amerikalılar kendilerine hakikati gösteren bir ayna tuttuğunu hissediyorlar" (Lucie-Smith, 2002, s. 126) sözleriyle sanatçıdan bahseder. Bu noktada Hopper'1 anlamak için Amerikan toplumunda yaşanan iki önemli olaydan da bahsedilmesi gerekmektedir. Birincisi, Amerika'nın iki dünya savaşını birden yaşayan ülkelerden birisi olmasıdır. Tanilli'nin (2007, s. 248) dediği gibi özellikle I. Dünya Savaşı'na göre çok daha yıkıcı sonuçlara sahip olan ve Amerika'nın da bütün gücüyle içerisinde yer aldığı II. Dünya Savaşı neredeyse tüm dünyayı bir savaş alanına çevirmiştir. Böylesine bir savaşın yaralarının Amerikan toplumu açısından hissedilmemesi imkânsızdır ve bu toplumun bir bireyi olarak Hopper'ın da bu durum karşısında kayıtsız kaldığı düşünülemez. Bu yüzden sanatçının resimlerindeki figürlerin endişeli ve huzursuz halleriyle savaş psikolojisi arasında bir bağ kurulabilir. Diğer önemli konu 1929'da Amerika'da başlayan ve neredeyse on y1l süren "Büyük Buhran" adını taşıyan kapitalizmin geçirdiği krizdir ve bu kriz Amerikan halkını oldukça derinden etkilemiştir. Nevins \& Commager'in ABD Tarihi isimli kitabında "ülkenin tarihindeki en yıkıcı kriz" olarak nitelenen bu buhranın sonuçları ve toplumdaki karşılı̆̆ şu şekilde ifade edilmektedir;

Ticari firmalar kapılarını kapadı, fabrikalar çalışmayı durdurdu, bankalar iflas etti. Milyonlarca işsiz sokaklarda boş yere iş arayarak dolaşıyordu. Yüz binlerce aile evlerini ellerinden çıkardı, vergi tahsilatı, şehir ve kasabaların okul öğretmenlerine maaşlarını veremeyecekleri bir dereceye düştü, inşaat işleri adeta tamamen durdu, daha önce kötü bir duruma düşmüş olan dış ticaret o zamana kadar görülmemiş bir seviyeye indi (Nevins \& Commager, 2008, s. 389).

Böylesine geniş çaplı bir krizin birey üzerinde yarattığı etkilerin sanatçının resimlerinde yer alması oldukça olası bir durumdur. Ancak bahsedilen tüm bu sosyal koşulların yansımaları Hopper'ın resimlerinde doğrudan yer almaz; binalar arasında figürlerin konumlanışı, figürler arasındaki kopukluk, terkedilmiş metropol havasıyla yaratılan gizemli atmosfer, 1şık-gölgenin yarattığı kontrastlar gibi metaforlarla dolaylı olarak yer alır. Bu sebeple sanatçının resimleri, ressamın yaşadı̆̆ dönem ve coğrafya (1882-1967) ile ilişkilendirilmezse günlük yaşamın sıradan anları olarak değerlendirilecek ve resimde tercih edilen sade anlatımın altında yatan derinliğe ulaşılamayacaktır. 


\subsection{Automat (1927)}

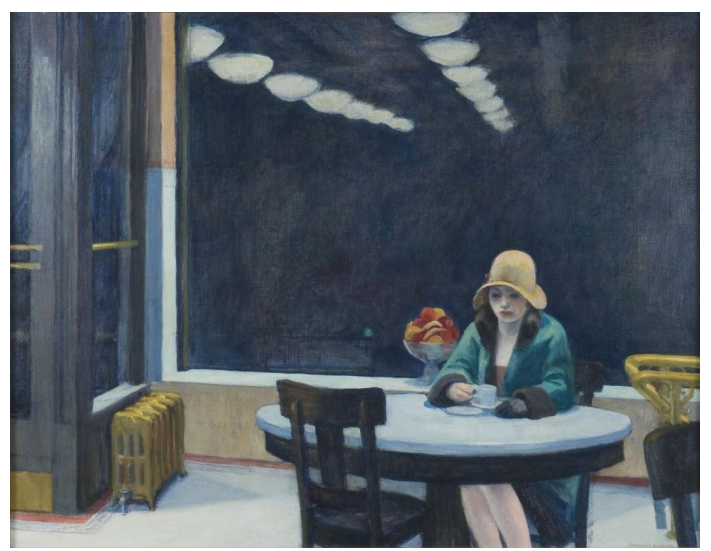

Görsel 1. Edward Hopper, “Automat”, $71.4 \times 91.4$ cm, tuval üzerine yağll boya, 1927, Des Moines Sanat Merkezi, Des Moines.

Edward Hopper'ın “Automat” (bkz. Görsel 1) isimli resminde yalnız başına kafeteryada oturan bir kadın görünmektedir. Kadının arkasında kalan ve kompozisyonun büyük kısmını oluşturan cam, aydınlatmaların yansıması dışında neredeyse tümüyle siyah bir leke halindedir. Yansıyan ışıklar ve resmin sağında bir kısmı görünen sandalyeler mekânın geriye ve sağa doğru devam ettiğini hissettirirken aynı zamanda figürün tek başına olduğu izlenimini verir. En önde duran boş sandalye de bu duyguyu güçlendirir. Kadın ve camekânın arkasında kırmızı tonların hâkim olduğu meyve dolu bir tabak, resmin solunda tamamı görünmeyen kapı ve radyatör bulunmaktadır.

Sarı şapkası ve kürklü yeşil montuyla kapıya en yakın masada oturan, kahve içmek için uğradığı bir mekânda bile eldiveninin tekini çıkarmayan figürün bu hali kısa bir süre için orada kalacağını düşündürür. Mekânın kafe, restoran tarzı bir yer olduğu belli olmasına rağmen bu konuda resme bakarak daha fazla bir şey söylemek mümkün değildir. Ancak sanatçının resme verdiği "Automat" (Otomat) ismi, mekânın nasıl bir yer olduğunu anlamamızı sağlar. Amerika'da ilki New York'ta 1912 yılında açılan otomat kafeteryaları, "madeni para ile çalışan makineler tarafindan yiyecek ve içeceklerin dağıtıldığı ucuz modern kafeteryalardır" (Doss, 2015, s. 6) diye tanımlayan sanat tarihçisi Erika Doss, bu mekânların insanlara zaman kazandırdığını söyler. Bu noktada figürün otomatta kahve içmesi ile kıyafetlerini çıkarmayarak kapıya yakın oturması arasında "zaman” bağlamında ilişki olduğu kuşkusuzdur. Otomatlarla ilgili yine Doss'un (2015, s. 6) ifadelerinden anlaşılacağ üzere bu alanlar sosyal iletişimin yoğun olduğu yerlerdir. Ancak resmedilen otomatın bu özelliği taşımadığı görülür. Ayrıca New York gibi hareketli gece hayatına sahip bir şehrin bu kadar karanlığa gömülmesi, camda meyve tabağının solunda görülen neyin yansıması olduğu belli olmayan yeşil ışık ve aydınlatmalar dışında herhangi bir yansıma olmaması bu sahnenin gerçekliğini sorgulamamıza sebep olmaktadır. $\mathrm{Bu}$ konuyla ilgili olarak yazar Louis Shadwick (2011, s. 47) kadının da odanın da bir yanılsama olduğunu söyler ve bu ifadesi odadaki sıra dışılığın bir açıklaması olabilir.

Resimdeki öğelere bakıldığında; acelesi olan bir kadın, yalnızlık vurgusu ve otomat adı verilen mekanik bir kafeterya öne çıkmaktadır. Bu üç öğenin doğrudan 1900'lerin Amerika'sını ve modern hayatı tarif ettiği açıktır. Bu sebeple sanatçının bu çalışması modern hayatın gelişimiyle yeni bir boyut kazanan makine-insan ilişkisi ve bu ilişkinin sonuçlarını anlatır. Sanatçının mekân olarak tercih ettiği otomat; makineyi, yani teknolojiyi temsil eder, bu mekânda herhangi bir otomatik alet görmememiz ise teknolojinin her yerde olduğunun ve tüm yaşamı değiştirdiğinin işaretidir. Fabrikada başlayan ve etkileri yaşamın her alanına yayılan teknoloji; insanın ilişkilerini, zaman algısını ve bunların paralelinde duygu durumunu da değiştirmiştir. Bu yeni duygu durumunun sebebi, makineyi yaratan insanın, artık onun 
belirlediği dünya düzeninde yaşamak zorunda kalmasıdır. Tüm bu durum sonucunda, resimdeki kadın “... 'belli bir zaman çerçevesi içine hapsedilmiş' bir halde, 'gecikme korkusundaki bir kalabalığın ortasında bunaltıcı bir yarış' a sürüklenmiştir..." (Tanilli, 2007, s. 559). Acelesi olması da bu sebeptendir.

Kadını kahve içmek için otomata girmeye teşvik eden şey vitrinde yer alan meyve dolu tabaktır. İçerinin, gecenin 1ssız karanlığından daha farklı olduğu mesajını veren meyve tabağı kapitalizmin ışıklı ve renkli aldatmacalarından biri olarak yorumlanabilir. Kadın, bahsedilen aldatmacanın peşinden girdiği bu mekânda da kaderini değiştirememiştir. Hatta gecenin karanlığında tümüyle görünmeyen modernitenin derinleştirdiği yalnızlığı kafeteryanın sert ışığında daha da görünür olmuştur.

\subsection{Room in New York}

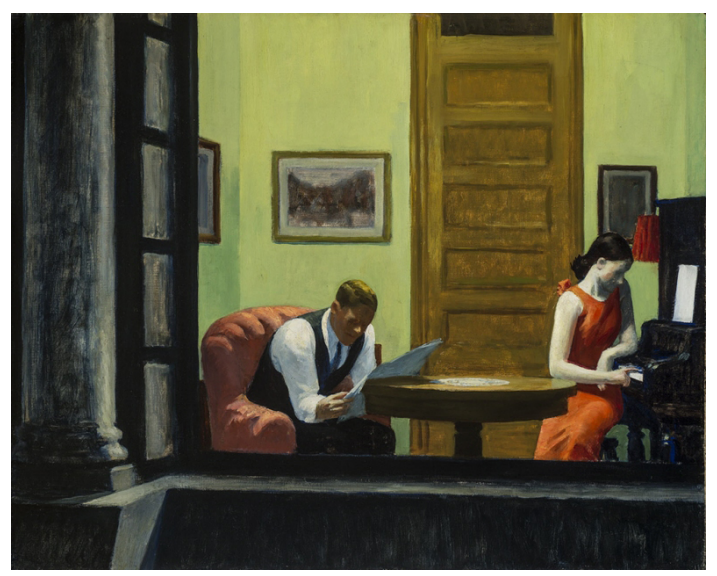

Görsel 2. Edward Hopper, "Room in New York”, 73.5x91.5 cm, tuval üzerine yağll boya, 1932, Sheldon Sanat Müzesi, Nebraska.

Yuvarlak bir masa etrafinda oturan iki kişinin açık bir pencereden göründüğü "Room in New York" (bkz. Görsel 2) isimli eser, Hopper'ın yalnızlık vurgusu yaptığı resimlerindendir. Resmin solunda tek kişilik bir koltukta oturan erkek figür masaya dayadığı gazetesini okurken, kadın; gövdesini, dirseğini yasladığı masanın aksi yönünde çevirmiş sağ elinin işaret parmağıyla piyanonun tuşlarına dokunmaktadır. Oda güçlü bir 1şıkla aydınlatılmıştır. Soldaki figürün arkasında görünen duvar ile piyanonun arasındaki mesafe düşünüldüğünde odanın hayli dar olduğunu söylemek mümkündür. Sanatçının odaya açık pencerenin boşluğundan bakışı, duvarda asılı olan çerçeveler, kapı, figürler ve

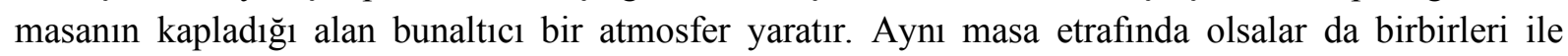
alakasız görünen bu iki figürün arkasında yer alan kapı, figürler arasındaki iletişimsizliği güçlendirir. Sanatçı bu resimde mekânla figürlerini yakınlaştırmış, bu sayede aralarındaki zihinsel uçurumu daha da çarpıcı hale getirmiştir. Mekânın, resimde anlatılmak istenen hikâyenin gücünü arttırmak için kullanılmasını yazar Winfried Fluck şöyle açıklar;

Sanatçının mekân ve sahneleri, figürler için bir ruh hali ve atmosferik bir ortam yaratmak için oradadır. Bu anlamda, mekân oldukça tiyatral bir özelliğe sahiptir (Fluck, 2009, s. 323).

Fluck'ın söylediklerine paralel olarak bu resimde özellikle figürlerin ruhsal durumu, yalnız ve iletişimsiz halleri mekân aracılığıyla vurgulanmış, figürlerin sıkışmışığı bu yolla hissettirilmiştir.

Hopper'ın sanki çevredeki binaların birinden izlenen penceresi, resimde aynı odayı paylaşan çiftin özel hayatının gözetleniyor olduğunu gösterir. $\mathrm{Bu}$ iki figürün birbirleriyle ilişkisiz halleri, gözetlendiklerinden habersiz olmaları dolayısıyla oldukça önemli bir gerçeği, modern hayatın beraberinde getirdiği yalnızlık ve yabancılaşmayı gözler önüne serer. Ancak modern hayat içerisinde sıkışıp kalmış iki figürün tasviri bize bundan çok daha fazlasını söylemektedir, yan yanayken bile 
yalnızlığın bu kadar derinleştiği bir dünyanın karamsar bir yansımasıdır bu resim. Birbirleri ile hiç alakası yokken aynı masa etrafında oturmaları da bu sebepten ötürüdür. Simmel'in metropol hayatı için söylediği “...bedensel yakınlık ve mekân darlığı, zihinsel uzaklığı daha da görünür kılmaktadır” (Simmel, 2003, s. 96) sözleri adeta bu resimdeki atmosferin açıklamasıdır. Sanatçı bu gerçeğe şahit olmamızı istediği için bu sahneyi açı pencereden gözetlememize müsaade eder.

\subsection{New York Movie (1932)}

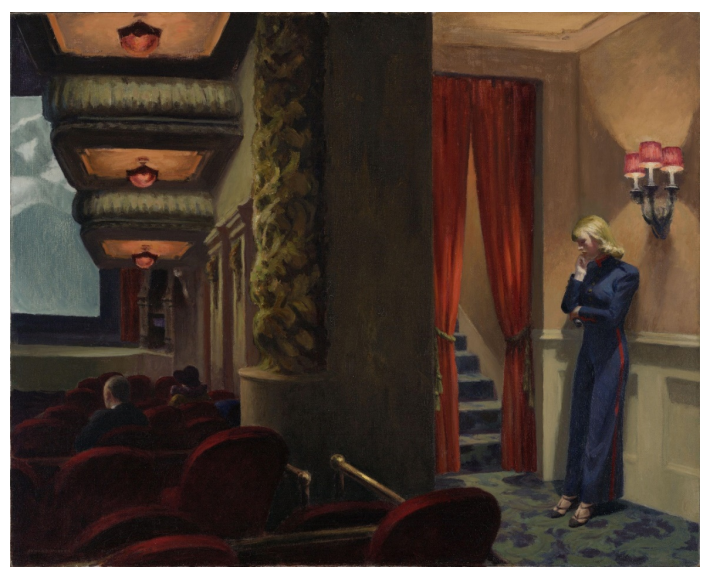

Görsel 3. Edward Hopper, "New York Movie”, $81.9 x 101.9$ cm, tuval üzerine yağll boya, 1939, Modern Sanatlar Müzesi, New York.

Bir sinema salonu ve salona giriş koridorunun birlikte tasvir edildiği "New York Movie" (bkz. Görsel 3) isimli resimde, gösterişli bir sütun bu iki alanı birbirinden ayırır. Resmin solunda görülen kırmızı kadifemsi koltuklardan sadece ikisi doludur ve bu iki izleyici farklı yerlerden filmi izlemektedirler. Koltukların ve tavandaki aydınlatmaların siyah beyaz bir filmin oynadığı ekrana doğru uzanışı mekânda derinlik hissi yaratır. Resmin sağında ise aydınlatmanın asılı olduğu duvara yaslanan ve elinde fener tutan bir kadın teşrifatçı görünmektedir. Bu kadın çıkış kapısının hemen yanında, sol elini göğsünün üzerine katlamış ve diğer elini yüzüne dayamış düşünceli bir halde durmaktadır.

Sinema salonunun karanlığı ve $1 s ̧ ı l_{1}$ koridor arasında yaratılan tezatlık teşrifatçı ve izleyiciler arasındaki kontrastlığı da yansıtmaktadır. İzleyiciler aksiyon dolu bir dünyanın karşısında pür dikkat otururken, teşrifatçı zihnen o salonda bile değildir. Hopper, kompozisyon kurgusunda net bir şekilde izleyiciden ayırdığı teşrifatçıyı 1şıklar altında öne çıkarırken, modern bireyin yalnızlığını da vurgulamaktadır. Aynı zamanda sinema görevlisinin bir filmi defalarca görmek durumunda kalması nedeniyle yaşadığı "yabancılaşma" ve "bıkkınlık" modern şehir hayatının kaçınılmaz bir gerçeğidir. Simmel bu gerçeği "Bıkkınlık-belki de başka hiçbir ruhsal fenomen, metropolle böylesine dolaysız bir bağ taşımaz" (Simmel, 2003, s. 91) sözleriyle ifade eder. Aynı zamanda "Bıkkın kimsenin gözünde her şey aynı donuklukta, aynı griliktedir; hiçbir nesne diğerinden daha ayırt edici değildir" (Simmel, 2003, s. 91) sözleri de teşrifatçının hayata bakışını özetler niteliktedir.

Sütunun ayırdığı iki alan arasında önemli paralellikler mevcuttur. Sağda yer gösterici, duvardaki aydınlatma ve perdenin arkasından merdivene geçilen kapı boşluğu bulunmaktadır. Solda ise tavanda arka arkaya sıralanmış aydınlatmalar, izleyiciler ve filmin oynadığı perde görünmektedir. Her iki tarafta da kullanılan benzer öğeler, birbirini çağrıştırmasının yanında gerçek ve gerçek olmayan bir dünya izlenimi yaratması sebebiyle birbirinden ayrılır. Bu noktada sanat eleştirmeni Peter Schjeldahl (2007) sinema salonu ile "Platon'un mağarası" arasında ilişki kurarak izleyicilerin sahte bir gerçeklik

' Platon (2010) tarafından ortaya atılan Antik Çağ felsefesine ait alegori. 
karşısında olduğunu söylemektedir. Gerçek olan ise teşrifatçının ruh halinde hayat bulan modern birey ve modernitenin yansımalarıdır.

\subsection{Nighthawks (1942)}

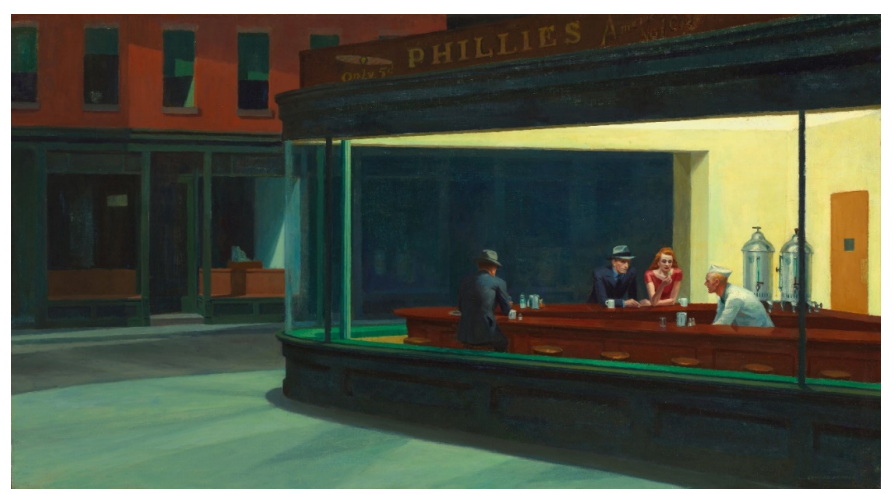

Görsel 4. Edward Hopper, "Nighthawks", $84 x 152$ cm, tuval üzerine yağlı boya, 1942, Chicago Sanat Enstitüsü, Chicago.

Hopper'ın en popüler resimlerinden olan "Nighthawks" (bkz. Görsel 4) sanatçının New York’ta küçük bir restoranda dört figürü konu aldığı çalışmasıdır. Restoran dışında her yerin kapalı olması ve herhangi bir yaşam belirtisi olmaması zamanın gecenin geç bir saati olduğunu gösterir. Resmin ismi de gece geç yatanlara verilen isim olan ve Türkçe gece kuşu sözcügünün karşıllğı Nighthawks'tur. Chicago Sanat Enstitüsü’nde yönetici olarak görev yapan Katie Rahn (2014) restoranın tüm sokağı aydınlatan güçlü 1şık kaynağının Amerika'da 1940'ların başlarında kullanıma giren floresanlar olduğunu söyler. Bu ışık sokağın karşısında boş görünen dükkânın vitrininde görünen yazar kasanın üzerine düşerek bu nesneyi tanımlamamızı sağlar.

Resimde, figürlerin birbirleriyle ilişkisi olduğuna dair herhangi bir işaret yoktur, bu konudaki tek ortaklıkları aynı mekânda buluşmuş olmalarıdır. Üçgen bir tezgâhın ortasında bulanan restoranın tek çalışanı işini yapmakta ve sırtı bize dönük figüre ya da restoranın dışında bir noktaya bakmaktadır. Resmin solunda yüzünü göremediğimiz, sırtı izleyiciye dönük şapkalı ve takım elbiseli bir figür bulunmaktadır. Yan yana duran kadın ve erkek figürü muhtemelen restorana beraber gelseler de Hopper'ın diğer çalışmalarında görüldüğü gibi birbirleriyle yan yana olmak dışında herhangi bir yakınlıkları yoktur. Restoranda görünen tek kapı bir çıkış kapısı olmaktan çok mutfak kapısını andırır. Ne restoran görevlisinin tezgâh arasından, ne de müşterilerin restorandan çıkabileceği bir kapının görünmemesi figürlerin bu mekân içerisinde tutsak olduklarına dair bir duygu yaratır. Bu duygu sanatçının diğer resimlerinde de görülen bireyin izolasyonunu anlatmaktadır.

Resimde tasvir edilenlere bakıldığında figürler arasında bir ilişki kurmak ve bu sahneyi öyküleştirmek oldukça güçtür. Sanatçı öykü anlatmaktansa insanların yalnızlıklarını öne çıkararak çok daha genel bir gerçeği göstermeye çalışmıştır. Figürlerin ilişkileri arasındaki belirsizlik, çok geç bir saatte bir arada bulunmaları ve neredeyse elleri birbirine değecek kadar yakın iki figürün bile birbirlerinden kopuk halleri, sadece resimdeki figürlerin değil bizlerin de bu dünyada tek başına olduğumuzu hatırlatır. $\mathrm{Bu}$ konuda sanat tarihçi Beth Harris ve Steven Zucker "Her şey yoruma açık, resmin bize anlattığı net bir öykü yok. Net olan tek şey bir başına, yalnız olma hissi. Yabancılaşma hissi” (Harris \& Zucker, 2018) dedikten sonra resmin yapım yılını düşünerek bu resmi, tüm şiddetiyle devam eden İkinci Dünya Savaşı'nın insanlar üzerinde yarattı̆̆ travmatik durumla ilişkilendirir. Murphy (2007) de figürlerin yorgun, endişeli ve birbirlerinden kopuk hallerini savaş zamanı huzursuzluğuyla açıklar. Hopper'ın sanat yaklaşımında Amerikan yaşam tarzına olan bağlılığ ve diğer resimlerindeki konu yaklaşımı düşünüldüğünde toplumsal anlamda böylesine büyük bir etki yaratan savaşa karşı kayıtsız kaldığ1 
düşünülemez. Bu resmin Pearl Harbour saldırısı sırasında yapılması da bu sahnenin savaş dönemiyle bağlantılı olma ihtimalini kuvvetlendirir. Restoran dışında görünen, tanımlayabildiğimiz tek nesne olan yazar kasa da bu bağlamda değerlendirilerek savaş zamanı Amerikan ekonomisi ile ilişkilendirebilir.

\subsection{Western Motel (1957)}

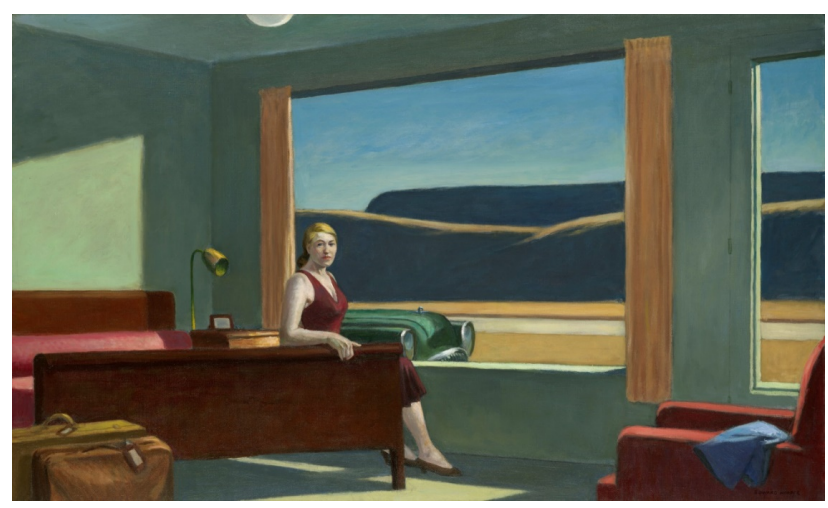

Görsel 5. Edward Hopper, “Western Motel”, $77.8 \times 128.3$ cm, tuval üzerine yağll boya, 1957, Yale Üniversitesi Sanat Galerisi, New Haven.

Western Motel (bkz. Görsel 5) isimli resimde motel odasında perdeleri sonuna kadar açılmıı̧ bir pencere önünde yatağın üzerine oturmuş bir kadın figürü bulunmaktadır. Bu figür Hopper'ın diğer resimlerinin aksine doğrudan izleyicinin gözlerinin içine bakar. Resmin sol alt köşesinde kapalı halde duran iki valiz, sağda bir kısmı görünen koltuk ve bu koltuğun üzerinde odadaki tüm geometrik yapının aksine dağınık duran bir kumaş parçası bulunmaktadır. Kadının arkasında yer alan komodinin üzerinde bir gece aydınlatması ve fotoğraf çerçevesi vardır. Perdeleri sonuna kadar açılmış pencerenin önünde, sadece ön kısmı görünen 1954 model Buick marka bir otomobil dururken, arabanın arkasından görünen manzara; odadaki geometrik yapıya benzer bir şekilde oluşturulmuş uzun çimenli tepeler ve boş bir araç yolundan ibarettir. Arabanın adeta kadının gövdesinin bir parçasıymış gibi durması, figür ve araç arasında ilişki kurmamızı sağlar. Sanatçının diğer resimlerindeki gibi 1şık odaya sert bir şekilde düşmekte ve gölgeli alanlar ile arasında derin kontrastlar oluşturmaktadır.

Mekân olarak tercih edilen motel; çoğunlukla karayolları üzerinde bulunan ve araçlariyla yolculuk yapanların ihtiyaçlarını karşılayabileceği küçük bir otel olarak görev yapar. Odanın bir motele ait olduğu resmin isminden anlaşıldığı gibi, önünde otomobilin durduğu ıssız bir yol kenarında olması ile de açıklanabilir. Kadının bize doğru kararlı bir şekilde bakışı yalnız olmadığını düşündürür, yatağın çift kişilik olması ve iki valizin resimde yer alması da odada başka bir kişinin bulunma ihtimalini güçlendirir. Buna rağmen resimde hâkim olan duygu Hopper'ın diğer çalışmalarındaki gibi yalnızlıktır. Valizlerin kapalı, yatağın toplanmış olması ve odada herhangi bir kişisel eşya görünmemesi ya henüz motele geldiklerini ya da toplanıp gitmekte olduklarını ifade eder.

Resimdeki hikâyenin ucu açıktır ve bu resim farklı okumalarla yorumlanabilir. Ancak bir motel odasında, yatağa eğreti bir şekilde oturmuş kadının oraya ait olmadığı açık şekilde görülür. Nereye ait olduğu konusu da muğlaktır. Bu belirsizlik izleyene bir huzursuzluk duygusu verirken, sanatçının diğer resimlerinin aksine kadının gözetlendiğinin farkında olması gerilimi arttıran bir öğe olarak kullanılmıştır. Bir güç nesnesi olarak algılanabilecek otomobil ise belki de kadının prangası durumundadir.

Daha açıklayıcı olmak gerekirse, bu resimde öne çıkan iki olgudan birincisi bir yere ait olamama durumu, diğeri de resimde görünmeyen ama motelle ilişkilendirdiğimizde anlayabildiğimiz seyahat halinde olma durumudur. Bu iki öğe metropol insanının yaşam tarzının bir sonucudur ve doğrudan 
modern yaşam şekliyle bağlantılıdır. Bu bağlantıyı akademisyen Nilüfer Talu'nun "Kalabalıkların adamı olarak modern birey evinden uzakta, kitlesel üretim koşullarının da etkisi ile yabancılaşmış, yersiz ve yurtsuz olarak kaydedilmiştir" (Talu, 2010, s. 163) sözleriyle açıklayabiliriz. Talu'nun bahsettiği modern bireyin bir yere ait olamama durumu Hopper'ın resminde bir motel odası ile anlatılmıştır. Yine Talu'nun (2010, s. 160) sanayi toplumu olmanın sonucu olarak bireyin bir yerden başka bir yere sürüklenmesi ifadesi de bu resimdeki seyahat halinde olma durumunun izahıdır. Bu sebeple otomobil, yolculuk ve motel ilişkisinin devamlılı̆̆ını sağlayan bir araç olarak 20. yy'ın devrim yaratan makinelerini simgelerken, aynı zamanda bireyin evsizliği ve bir yerden başka yere sürüklenme durumunun da sebebidir.

\section{Sonuç}

Hopper, sanayi alanında yaşanan büyük gelişmelerin toplumsal anlamda birçok dönüşüme sebep olduğu 20. yy Amerika'sında yaşamıştır. Bu dönemde sanayide yaşanan ilerlemeler makinenin başrolde olduğu birçok yeni üretim biçimini beraberinde getirirken, işçinin üretim sürecindeki konumunda da önemli değişikliklere yol açmış; bu değişikliklerin etkileri fabrikaların dışına çıkarak tüm sosyal hayatı kuşatmış ve modern yaşam tarzının temellerini oluşturmuştur. Kalabalıklaşan şehir nüfusu, ilerleyen teknoloji ve değişen yaşam koşulları bireyi yalnızlı̆̆a iterek kendisine yabancılaşmasına sebep olmuş, bu duruma ek olarak ülkesi dünya savaşlarına katılan Amerikan halkı oldukça ağır sonuçlarıyla yaklaşık on yıl süren bir ekonomik krizle yüzleşmek zorunda kalmıştır. Bu noktada çağının iyi bir gözlemcisi olan ve dış etmenlerden beslenen Edward Hopper, 1900'lerin Amerika'sını modernitenin beraberinde getirdiği çelişkilerle ilişkilendirir ve bu ilişkiyi tuvaline ustaca yansıtır. Sanatçının resimlerindeki modernlik, "Bizleri sürekli parçalanma ve yenilenmenin, mücadele ve çelişkinin, belirsizlik ve acının girdabına sürükler" (Berman, 1983, s. 27). Hopper, bu anlatımı ilk bakışta sıradan görülebilecek anların tasviriyle ifade eder. Bu sebeple her izleyicinin farklı okumalar yapabileceği bu resimlerde asıl anlam yüzeyde değil derinlerdedir ve derinlerdeki bu anlamı bulup çıkarabilmek ancak 20. yy Amerika'sının sosyal yapısı ile resimler arasında bağlantı kurulmasıyla mümkündür. Sanatçının eserlerini evrensel yapan da kurulan bu bağlantının modern çağın insanını dolayısıyla içinde bulunduğu toplumsal yapıyı tanımlayan tasvirler içermesidir.

\section{Kaynakça}

Berman, M. (1983). Katı olan her şey buharlaşıyor: modernite deneyimi (Ü. Altuğ, \& B. Peker, Çev.) İstanbul: İletişim Yayıncılık.

Doss, E. (2015). Hopper's cool: Modernism and emotional restraint. American Art, 29 (3), 2-27.

Fluck, W. (2009). Romance with America? essays on culture, literature, and American studies (L. Bieger, \& J. Voelz, Dü). Heidelberg: Universitätsverlag Winter.

Harris, B., \& Zucker, S. (2018, Aralık 01). Hopper, "Gece Kuşları" [Blog yazısı]. Erişim adresi: https://tr.khanacademy.org/humanities/art-1010/art-between-wars/american-art-wwii/v/edwardhopper-nighthawks-1942

Lucie-Smith, E. (2002). American realism. New York: Thames \& Hudson.

Murphy, J. (2007, Haziran). Edward Hopper (1882-1967) [Blog yazıs1]. Erişim adresi: https://www.metmuseum.org/toah/hd/hopp/hd_hopp.htm

Nevins, A., \& Commager, H. S. (2008). ABD tarihi (H. İnalcık, Çev.). Ankara: Doğu Batı Yayınları.

Pappenheim, F. (2002). Modern insanın yabancılaşması. Ankara: Phoenix Yayınevi. 
Platon. (2010). Devlet. (S. Eyüboğlu, \& M. A. Cimcoz, Çev.). İstanbul: Türkiye İş Bankası Kültür Yayınları.

Rahn, K. (2014, Mayıs 23). Acquiring nighthawks [Blog yazısı]. Erişim adresi: https://www.artic.edu/articles/471/acquiring-nighthawks

Schjeldahl, P. (2007, Mayıs 21). Ordinary people [Blog yazısı]. Erişim adresi: https://www.newyorker.com/magazine/2007/05/21/ordinary-people-2

Shadwick, L. (2011). The window and the void in the work. Bristol: University of Bristol.

Simmel, G. (2003). Modern kültürde çatışma. İstanbul: İletişim Yayıncılık.

Talu, N. (2010). Modernlik söylemi: endişeli bakışlarda modern birey. Orta Doğu Teknik Üniversitesi Mimarlık Fakültesi Dergisi, 27 (2), 141-171.

Tanilli, S. (2007). Yüzyılların gerçeği ve mirası (Cilt 6). İstanbul: Alkım Yayınevi.

\section{Görsel Kaynakçası}

Görsel 1. Hopper, E. (Sanatçı). (1927). Automat, 71.4×91.4 cm [Tuval üzerine yağlı boya]. Des Moines Sanat Merkezi, Desmoines. Erişim adresi: https:// emuseum.desmoinesartcenter.org/ objects/41752/automat?ctx=f0605cb3-1643-40c0-a391-b3830dc08d85\&idx=0\#show 1

Görsel 2. Hopper, E. (Sanatç1). (1932). Room in New York, 73.5x91.5 cm [Tuval üzerine yağlı boya]. Sheldon Sanat Müzesi, Nebraska. Erişim adresi: http:// emuseumplus.unl.edu: 8080/eMP/eMuseumPlus?service=direct/1/ResultDetailView/result.inline.list.t1.collection_list. $\$$ TspTitleImageLink.link $\& \mathrm{sp}=13 \& \mathrm{sp}=$ Sartist $\& \mathrm{sp}=$ SfieldValue $\& \mathrm{sp}=0 \& \mathrm{sp}=1 \& \mathrm{sp}=3 \& \mathrm{sp}=$ Sdetail View\&sp $=0 \& \mathrm{sp}=\mathrm{Sdetail} \& \mathrm{sp}=0 \& \mathrm{sp}=\mathrm{T} \& \mathrm{sp}=0 \& \mathrm{sp}=\mathrm{Sdetail}$ List $\& \mathrm{sp}=0 \& \mathrm{sp}=\mathrm{F} \& \mathrm{sp}=$ Scollection\& $\mathrm{p}=14940$

Görsel 3. Hopper, E. (Sanatçı). (1939). New York movie, 81.9x101.9 cm [Tuval üzerine yağl1 boya]. Modern Sanatlar Müzesi, Newyork. Erişim adresi: https: //rachedikamel.wordpress.com/ 2013/07/15/edward-hopper-new-york-movie/

Görsel 4. Hopper, E. (Sanatçı). (1942). NightHawks, 84x152 cm [Tuval üzerine yağlı boya]. Chicago Sanat Enstitüsü, Chicago. Erişim adresi: https: //en.wikipedia.org/wiki/File: Nighthawks_by_Edward_Hopper_1942.jpg

Görsel 5. Hopper, E. (Sanatçı). (1957). Western Motel, 77.8x128.3 cm [Tuval üzerine yağlı boya]. Yale Üniversitesi Sanat Galerisi, New Haven. Erişim adresi: https: //artgallery.yale.edu/ collections/objects/52875 